\title{
OPTIMISATION OF PROCESS PARAMETERS FOR M.A.G WELDING OF API X7OM MATERIAL TO PREDICT TENSILE STRENGTH USING TAGUCHI METHOD
}

\author{
N. S. Akonyi1,*, O. A. Olugboji², E. A. P. Egbe ${ }^{3}$, O. Adedipe ${ }^{4}$, S. A. Lawal5. \\ 1, SCIENTIFIC EquipMent DeVELOPMENT INSTITUTE, MinNA, NigER STATE, NIGERIA \\ $\mathbf{2 , 3 , 4 , 5}$ Dept of Mechanical Engineering, Federal Univ. Of TeChnology, MinNa, Niger State, Nigeria \\ Email addresses: ${ }^{1,}$ akonyi01@gmail.com, ${ }^{2}$ olugbojiolufemi@yahoo.com, ${ }^{3,}$ evus.egbe@gmail.com \\ 4, adelordy2002@yahoo.com, 5, lawalsunday@futminna.edu.ng
}

\begin{abstract}
Girth welded replica of API X7OM material have been produced on NG-GMAW welding technique. The particular area of interest is to develop suitable girth welding process parameter using NGGMAW. The major aim of the work was to replicate welds having tensile strength between 650 and $680 \mathrm{MPa}$. Design of Experiment (DoE) method by Taguchi design, using some selected welding processes was adopted. Two process parameters (factors) - arc voltage and wire feed rate, (the variables), and three levels were used. The resultant joint property on tensile strength of X70M pipeline was examined. The targeted mechanical property was achieved by selecting the best process parameters. Their effects on ultimate tensile strength - UTS was analysed using statistical technique - analysis of variance - ANOVA and Signal to Noise - S/N ratio with 'thebigger-the-better' value. Validation was done using MIDAS NFX (an FEA) mechanical engineering software. In conclusion, process parameters that affects or influences the girth welded properties of API X7OM under field conditions were identified. Guidance for the specifications and selection of processes that could be used in field-welding for optimum performance has been recommended.
\end{abstract}

Keywords: Optimization, Girth-Weld, Process Parameters, Tensile Strength, NG-GMAW

\section{INTRODUCTION}

The technological evolution in structural steels are pointing towards high strength steels for use in the deep offshore and marine applications. In order to meet up with the challenges of deep offshore hostilities, extensive efforts have been made to develop line pipe steel grades with superior metallurgical and mechanical (strength, toughness and ductility) properties in order to allow exploitation in such hostile environments. Metallurgical properties and information on processing such as chemical composition, microstructural design, thermo-mechanical controlled process (TMCP) and accelerated cooling process (AcC), to achieve the target strength, ductility and toughness properties are among factors to be considered in the new strategy. The new steel grades for these purposes can be seen as an advanced variant of high strength low alloy (HSLA) steels. HSLA steels typically contain very low carbon content and small amounts of alloying elements (micro-alloyed), such as Niobium, Vanadium, Titanium and Molybdenum.

The Research focus is to consider the detailed procedures for welding qualifications in order to prevent weld flaws which will eventually avoid weld repair. The strength of welded joints and weld dilution in the HAZ which is used to judge the quality of welds, has been the focus of many research [1]. Therefore, it is important that welding processes must be carefully selected to obtain this quality. However, the details about metallurgy of the material is not within the scope of this work.

\footnotetext{
* Corresponding author: +234 - $805-461$ - 6400
} 


\subsection{The Narrow Gap Welding (NGW)}

NGW is an advanced welding techniques [2], developed to reduce the volume of deposited metal with high economic advantage in welding, $[3,4]$. Figure 1 equally demonstrates the advantage in NGW of low volume of weld metal deposition.

The welding process completion time and welded metal samples increases, (i.e. more number of welded metal pieces are completed in less time due to low volume of deposition) when compared to the conventional V-groove preparation, see Figure 1. Pal et al [6] compared in area, (Table 1) the conventional V-groove with narrow groove for weld metal. This in turn offers financial benefits arising from lower material, i.e. less volume of metal deposition and fabrication costs.

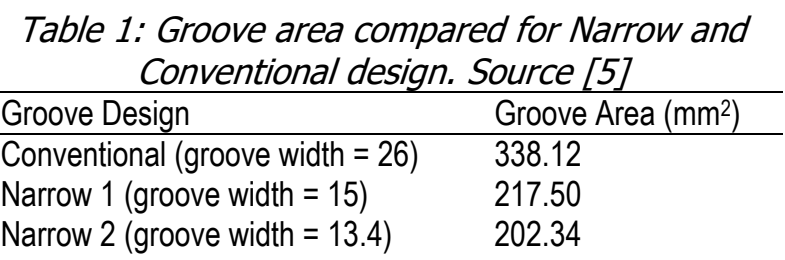

NGW techniques has been successfully applied for thickness of $50 \mathrm{~mm} \leq 300 \mathrm{~mm}[3,4]$, lower thickness has not been reported. This is one of the aims of this work.

Gas Metal-Arc Welding with Narrow Gap Welding (GMAW-NGW) was selected for this work. According to [6], GMAW process is versatile because it can be used by choosing the appropriate welding variables and in all positions. GMAW is a mechanised welding process whereby the molten metal and arc are shielded by an externally supplied gas. The filler metal is normally obtained from an electrode coil. It is adopted worldwide to construct pipelines on site. GMAW is categorised into MIG - Metal Inert Gas, and MAG - Metal Active Gas. The Metal Active Gas -
MAG, so named here because, an active gas has been used as shielding in this work.

The Narrow Gap (Groove) Welding was combined with GMAW welding to obtain higher productivity welding process in this work.

\section{BRIEF LITERATURE}

When lengths of individual pipelines are welded at their ends to form joints called 'girth welds', there are demands set to be achieved, especially at the welded region and heat affected zones. These set demands are the quality of strength, hardness and impact toughness, depending on the objectives, which are results of microstructures obtained from the weld process. [7 - 11]. This girth welded joints has been the focus of many research and investigations because it represents a significant portion in the pipeline with distorted microstructure (heterogeneous properties), unlike the base metal.

Researches on girth welds in pipeline steel are categorized by [12] into:

i. the study on welding process developments

ii. the study on weld metal properties

iii. the study on complete joint assessment and

iv. the study on the HAZ properties.

The interest of this work however, has direct implications to all of the above.

The methods of joining the pipe segments (or connecting the joints) are critical and very important in the design of pipeline. [13], specifies welding and joining methods for pipe. The reliability of welds is dependent on the materials employed and the welding processes used. The challenge for such welding especially for hostile environment is how to prevent the formation of brittle fractures in the welded joint and heat affected zone (HAZ). To overcome this challenge, a professional method is required to select suitable welding process parameters.

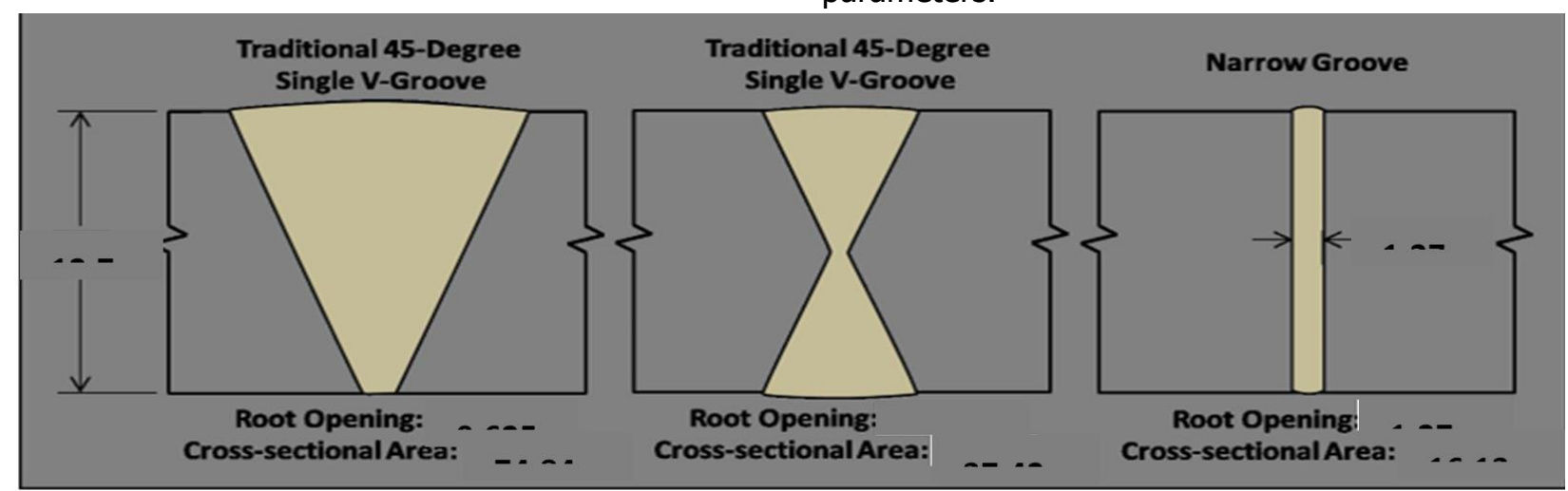

Figure 1: The art of narrow groove welding showing welds cross sectional area and material thickness. $A$ guide for joint preparation. (Source: [5]). 
This optimal process estimate low transition temperatures of weld for the material.

Although, Handbooks and "Rule of Thumb" has been used to determine the welding process parameter in some cases. This method rarely guarantees the desired quality due to equipment used and the environment [1].

The works of $[5,14-16]$ on the influence of narrow gap welding on mechanical properties of steel materials cannot be overemphasised. Narrow gap in combination with GMAW has been utilized by [17] on the study of arc characteristics and their influences on weld bead geometry in narrow gap GMAW as well as [18] on Characteristics of GMAW Narrow Gap Welding on the Armor Steel of Combat Vehicles. Also, Taguchi/DOE were used by $[6,19-$ 21] to optimise process parameters with excellent results.

To select parameters with optimal values, a design of experiment software, (DoE) - Minitab 17, with Taguchi design, was used to select and analyse responses.

The Taguchi design has lots of advantage. This includes process parameters optimisation to control quality, cost and productivity aspects [22]. In addition, Taguchi design has been successful in process performance and product quality improvement in the last seventeen years, [23]. High quality products are produced at reduced costs as a result of this powerful tool as it improves productivity during research and development. [19] A statistical package - analysis of variance - ANOVA, (also provided by the Taguchi design) was used to analyse the effects of different variables.

\section{MATERIALS AND METHODS 3.1 Materials}

A $300 \mathrm{~mm} \times 105 \mathrm{~mm} \times 20.62 \mathrm{~mm}$ plate of API 5L70M PSL2 was acquired as the base material. The Chemical composition as analysed using Optical Emission Spectroscopy - (OES) test is shown in table 2. This was analysed by Nigeria Machine Tools, Osogbo.

\subsection{Method}

\subsubsection{Optimisation of process parameters in MAG welding.}

Two welding parameters (factors), the arc voltage and wire feed rate with three levels of each factors were selected for experimentation. The Taguchi's method of experimental process using column of $L_{9}$ $\left(3^{2}\right)$ orthogonal array was used as shown in Table 3. Based on this, nine (9) weld trials were performed with strict adherence to the design conditions shown in Table 3.

\subsubsection{Preparation of base metal and welding process.}

The welding process parameters selected for this study are: welding arc voltage and wire feed rate. The plate (base metal) was prepared into a single $\mathrm{V}$ groove edge as shown in Figure 2. The prepared edges were properly cleaned to remove unwanted inclusion that could affect the weld quality.

ER70s-6 type electrode was the filler materials with $1.2 \mathrm{~mm}$ thickness, acquired for the weld. Nine samples were used for this experiment in accordance with the DoE.

Table 2: Chemical composition

\begin{tabular}{lccccccccc}
\hline Element & $\mathrm{C}$ & \multicolumn{2}{c}{$\mathrm{Si}$} & $\mathrm{Mn}$ & $\mathrm{P}$ & $\mathrm{S}$ & $\mathrm{Cr}$ & $\mathrm{Ni}$ & $\mathrm{Cu}$ \\
\hline Chemical Composition & 0.054 & $\mathrm{C}$ & 0.188 & 1.50 & 0.005 & 0.003 & 0.222 & 0.006 & 0.003 \\
\hline $\mathrm{Al}$ & $\mathrm{V}$ & $\mathrm{Mo}$ & $\mathrm{Ti}$ & $\mathrm{B}$ & $\mathrm{Pb}$ & $\mathrm{C} 0$ & $\mathrm{~W}$ & $\mathrm{Sn}$ & \\
\hline 0.031 & 0.021 & 0.178 & 0.023 & 0.0025 & 0.003 & $<0.002$ & $<0.02$ & $<0.003$ \\
\hline
\end{tabular}

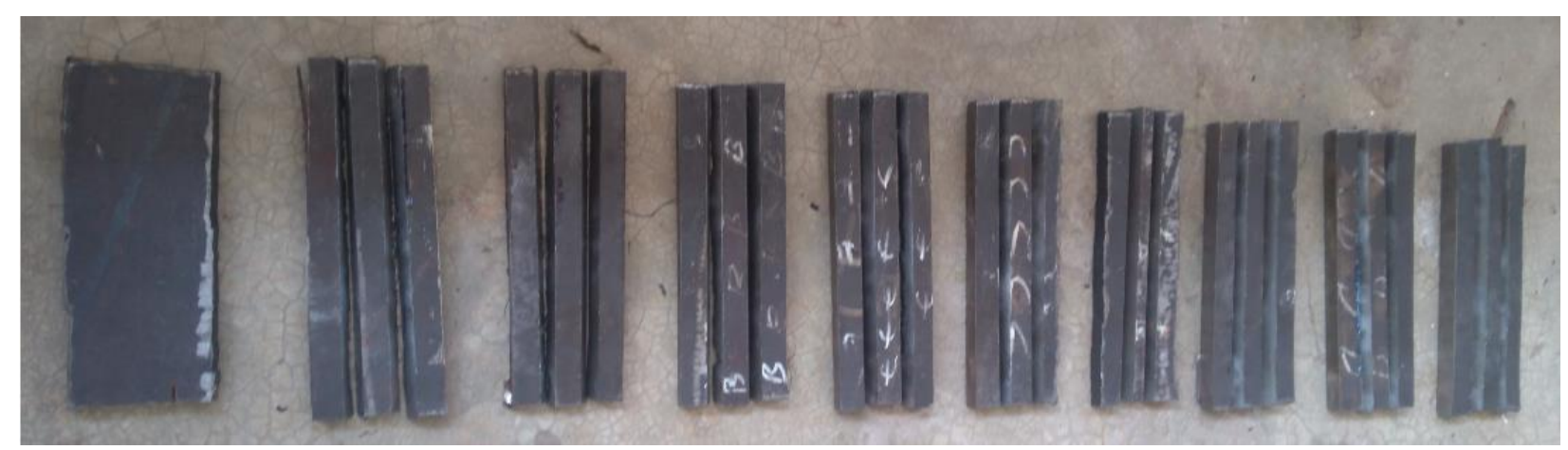

Figure 2: The API X7OM base material prepared for welding. 
The material samples were welded along the rolling (longitudinal) direction with an uphill fill welding. $\mathrm{CO}_{2}$, the shielding gas was used at the same regulator settings. Standard procedures similar to those used for cold region fabrications were carefully applied. Settings of parameters on the welding machine were done in accordance with orthogonal array designs from Taguchi's method and were appropriately applied. Welding was conducted by qualified personnel on KEMPPI 323R welding equipment at the Mechanical Engineering workshop, Federal University of Technology, Minna. Nigeria. The resulting welded sample is shown in Figure 3.

\subsection{Determination of Ultimate Tensile Strength.}

A circular tensile test piece standard, 2-step grip shaped specimens were used for the tests (Figure 4).

The test specimens were extracted on the welded part as shown in figure 5 and prepared to standard size, (Figure 4) according to the universal testing equipment specifications.

The specimens were fixed to the UTM to generate stress- strain curves. The curve was used to determine the force, and the ultimate tensile strength and were evaluated.

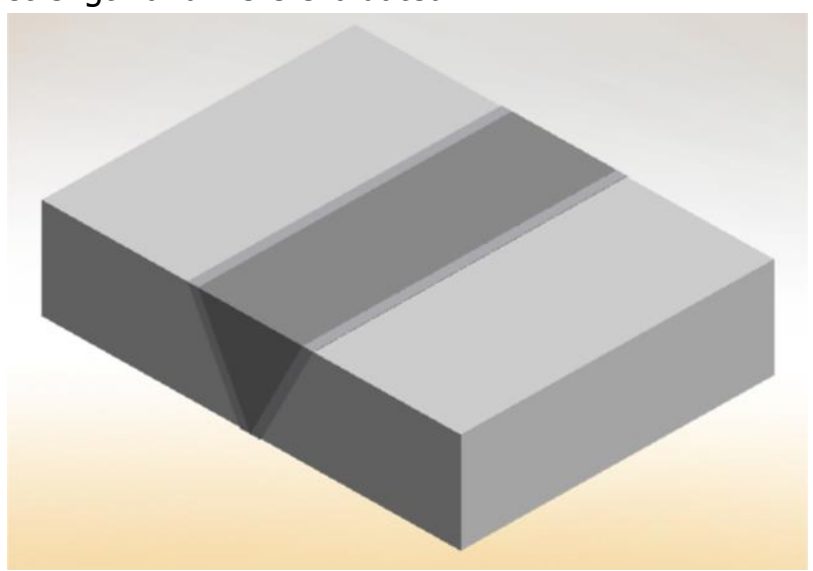

Figure 3: Welded and machined material

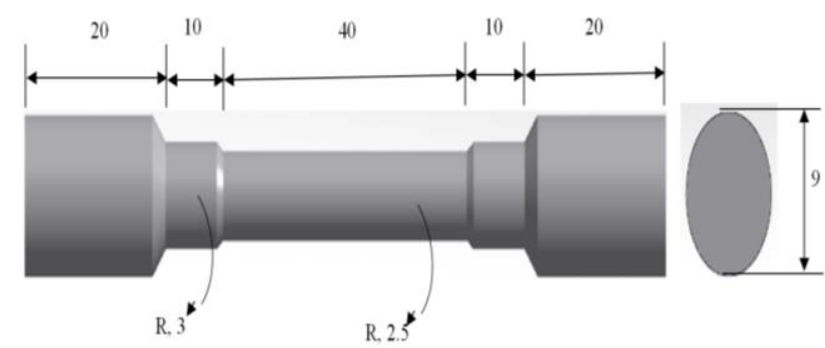

Figure 4: Sample of tensile specimen. (All dimension in, $\mathrm{mm}$.)

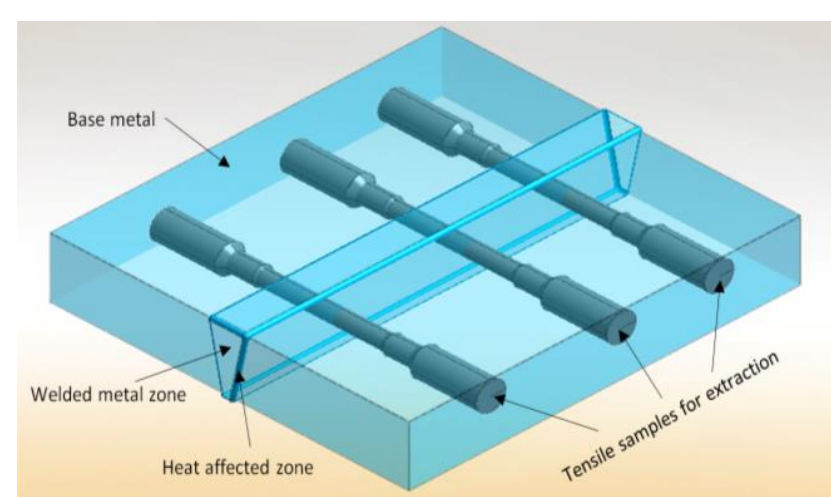

Figure 5: Format for extraction of tensile specimen

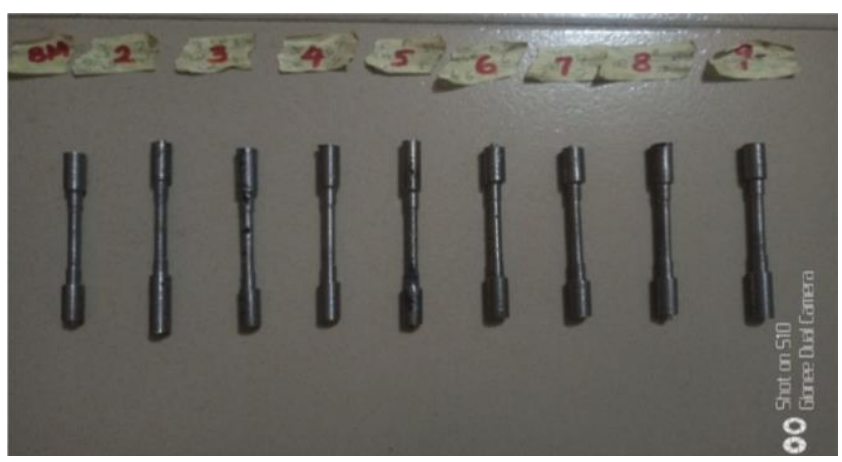

Figure 6: Extracted tensile specimens machined for the Test.

Table 3: Experimental Design Matrix.

\begin{tabular}{ccc}
\hline $\begin{array}{c}\text { Weld Trials } \\
\text { (WT) }\end{array}$ & $\begin{array}{c}\text { Arc Voltage } \\
(\mathrm{V})\end{array}$ & $\begin{array}{c}\text { Wire Feed Rate } \\
(\mathrm{m} / \mathrm{min})\end{array}$ \\
\hline 1 & 20 & 3.6 \\
2 & 20 & 4.5 \\
3 & 20 & 5.4 \\
4 & 25 & 3.6 \\
5 & 25 & 4.5 \\
6 & 25 & 5.4 \\
7 & 30 & 3.6 \\
8 & 30 & 4.5 \\
9 & 30 & 5.4 \\
\hline
\end{tabular}

Tensile tests were carried out using the Instron universal tester (Model No. 3369, USA), to determine the ultimate tensile strength. The tests were done at the engineering materials laboratory of Engineering Materials Development Institute, EMDI, Akure, Ondo State, under ambient conditions at a loading rate of $50 \mathrm{~mm} / \mathrm{min}$, with maximum load of $50 \mathrm{kN}$ applied. The average of three reproducible specimen results was reported.

Note that no heat treatment was done to the material and no effects of machining on the samples was considered in this work. 


\section{RESULTS OF THE EXPERIMENT}

The tensile stress results of the nine experimental weld trials are shown in Table 4. The average values of three readings were recorded for each weld trial. Equally, the S/N ratios of UTS for each are also included.

\subsection{Analysis}

Analysis of variance - ANOVA was used to analyse the results while MIDAS NFX software was also used to compare and validate the results of the tensile test. Design of experiment using Minitab 17 software was used to check the optimum process factors suitable for the work.

\subsubsection{Signal to noise ratio calculation}

This was calculated using Larger-the better quality characteristics shown in Equation 1

$$
\text { Larger }- \text { the }
$$

Where $\mathrm{k}=$ mean, $\mathrm{i}=$ Ith trial and $\mathrm{n}=$ number of trials.

The main effects plots are shown in Figure 7. The main effects plot shows that optimal tensile strength can be obtained using Arc Voltage (V) of $30 \mathrm{~V}$ and Wire Feed Rate of $4.5 \mathrm{~m} / \mathrm{min}$.

\subsubsection{Analysis of variance (ANOVA)}

The ANOVA table for Tensile strength is shown in Table 6. The ANOVA showed that Arc voltage has the most significant contribution on the tensile strength with a percentage of $52.95 \%$, while the wire feed rate has a contribution of $39.60 \%$. The error is $7.45 \%$.

\subsubsection{Regression equation}

The full quadratic equation and the respective correlation coefficient (Rsq) for tensile strength is shown in Equation 2.

Tensile strength $=-4671+205 \mathrm{AV}+1138 \mathrm{WFR}$

$$
\begin{aligned}
& -2.13 \text { AV X AV - 79 WFR X WFR } \\
& -18.8 \text { AV X WFR }
\end{aligned}
$$

Where $A V=$ Arc Voltage, WFR=Wire Feed Rate.

\subsubsection{Contour and $3 \mathrm{~d}$ surface plots}

The contour and 3D surface plots for tensile strength are shown Figure 7 and 8. These plots indicate how changes in two experimental factors affect the experimental responses.

Table 4: Shows the summary of results of the tensile test.

\begin{tabular}{cccc}
$\begin{array}{c}\text { Weld Trials } \\
\text { (WT) }\end{array}$ & $\begin{array}{c}\text { Arc } \\
\text { Voltage } \\
\text { (V) }\end{array}$ & $\begin{array}{c}\text { Wire Feed Rate } \\
\text { m/min }\end{array}$ & $\begin{array}{c}\text { Tensile } \\
\text { strength }\end{array}$ \\
\hline 1 & 20 & 3.6 & 225.02 \\
2 & 20 & 4.5 & 435.02 \\
3 & 20 & 5.4 & 460.95 \\
4 & 25 & 3.6 & 660.21 \\
5 & 25 & 4.5 & 535.62 \\
6 & 25 & 5.4 & 298.42 \\
7 & 30 & 3.6 & 553.31 \\
8 & 30 & 4.5 & 545.00 \\
9 & 30 & 5.4 & 450.06 \\
\hline
\end{tabular}

Table 5 shows the results of the experiment and $S / N$ ratios values.

\begin{tabular}{ccccc}
\hline $\begin{array}{c}\text { Weld } \\
\text { Trials } \\
\text { (WT) }\end{array}$ & $\begin{array}{c}\text { Arc } \\
\text { Voltage } \\
\text { (V) }\end{array}$ & $\begin{array}{c}\text { Wire } \\
\text { Feed } \\
\text { Rate } \\
\text { (WFR) } \\
\text { m/min }\end{array}$ & $\begin{array}{c}\text { Tensile } \\
\text { strength } \\
\text { (MPa) }\end{array}$ & $\begin{array}{c}\text { S/N } \\
\text { Ratios } \\
\text { values } \\
\text { (dB) }\end{array}$ \\
\hline 1 & 20 & 3.6 & 225.02 & 47.0444 \\
2 & 20 & 4.5 & 435.02 & 52.7702 \\
3 & 20 & 5.4 & 460.95 & 53.2731 \\
4 & 25 & 3.6 & 660.21 & 56.3936 \\
5 & 25 & 4.5 & 535.62 & 54.5771 \\
6 & 25 & 5.4 & 298.42 & 49.4966 \\
7 & 30 & 3.6 & 553.31 & 54.8594 \\
8 & 30 & 4.5 & 545 & 54.7279 \\
9 & 30 & 5.4 & 450.06 & 53.0654 \\
\hline
\end{tabular}

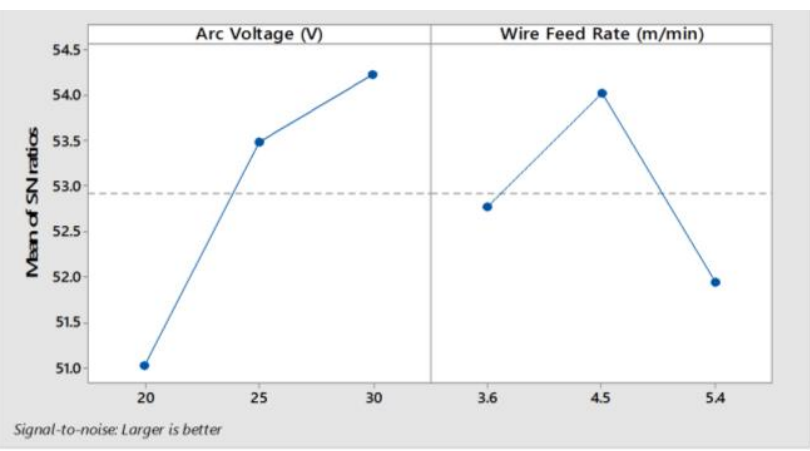

Figure 7: Main effects plot for Tensile strength

Table 6: ANOVA for tensile strength.

\begin{tabular}{llllll}
\hline Factor & DOF & SS & MS & F & $\mathrm{P}(\%)$ \\
\hline Arc Voltage $(\mathrm{V})$ & 2 & 76101 & 38050.5 & 14.214322 & 52.95 \\
Wire Feed Rate & 2 & 56911 & 28455.5 & 10.629969 & 39.6 \\
Error & 4 & 10707.651 & 2676.91 & & 7.45 \\
\hline Total & 8 & 143719.65 & 17965 & & 100 \\
\hline
\end{tabular}




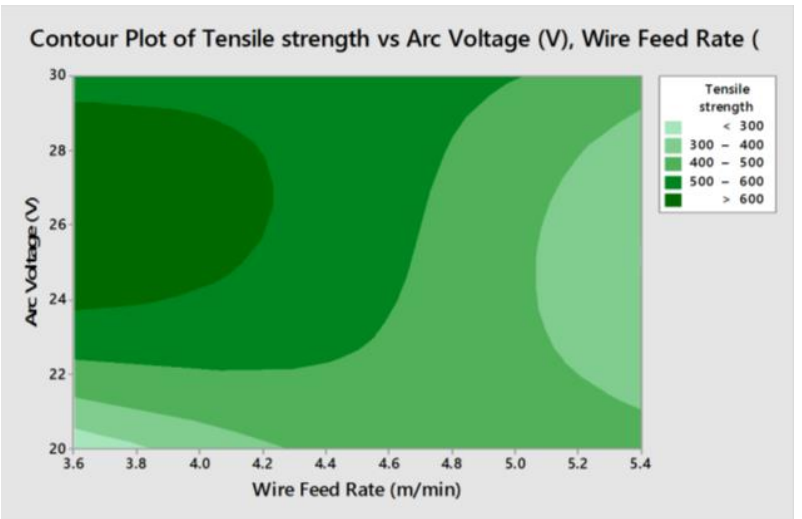

Figure 8: Contour plots

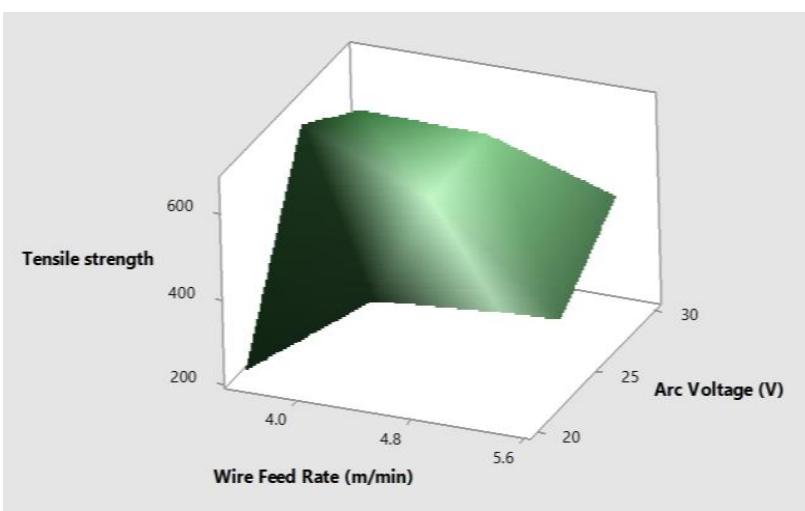

Figure 9: 3D surface plots.

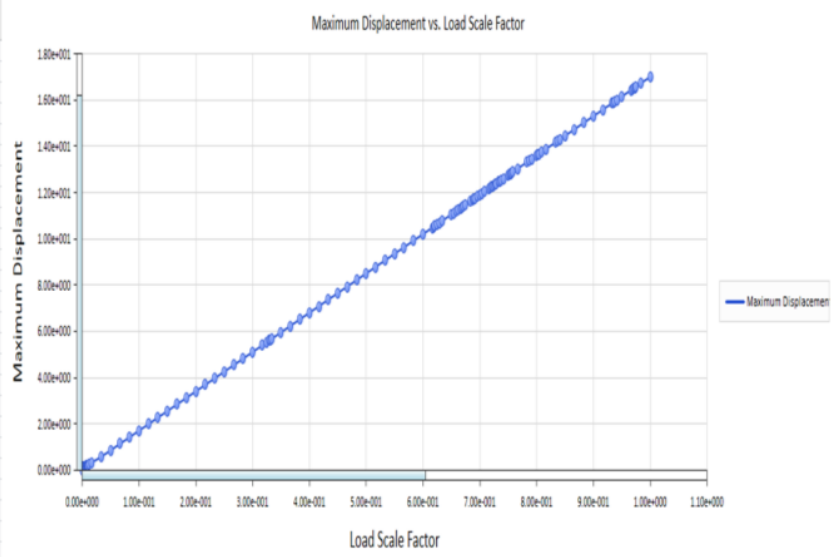

Figure 10: Displacement versus load scale factor.



Figure 11: Maximum and minimum solid stresses at break

Nigerian Journal of Technology,

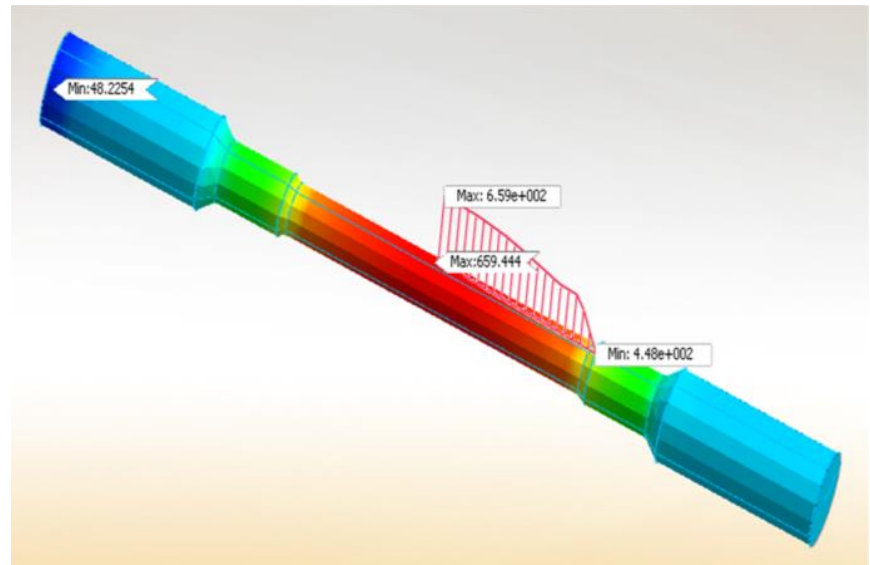

Figure 12: On-Curve plot of maximum and minimum points.

As shown in Figures 8 and 9, it can be observed that tensile strength of greater than $600 \mathrm{MPa}$ can be obtained using an arc voltage between 24 and 29 volts and wire feed rate of less than $4.2 \mathrm{~m} / \mathrm{min}$.

\subsection{FEA analysis for validation}

In order to validate the experimental work, the stress - strain data were computed into the MIDAS NFX software with the following results.

\section{DISCUSSION}

The tensile test results of the welded joints on all the specimens indicates that the joints have superior tensile properties. They all failed along the base metal and the heat affected zones on all the weld trials. This shows that the weld metal zone is stronger than the base metal and heat affected zone. Conversely, hardness test results also indicate that the region of failure is soft, compared to other region in the specimen. This may be attributed to heat input as a result of thermal cycles during the welding process.

The ANOVA analysis shows that Arc voltage has the most significant contribution on the tensile strength with a percentage of $52.95 \%$, while the wire feed rate has a contribution of $39.60 \%$ with error of $7.45 \%$. This is because the filler metal electrode in GMAW is always connected to the positive terminal (reverse polarity) of the direct current known as 'direct current reverse polarity' (DCRP). The amount of heat generation in GMAW process is large, approximately two thirds of total heat generated at the filler metal end. The heat generated was as a result of the arc voltage which enhances the arc temperature that increases the peak temperature of 
the molten metal pool. Depth of penetration is enhanced by arc voltage too, a phenomenon good for the objective of this work.

\subsection{Tensile Properties}

The engineering stress-strain curves of the nine weld trials (at room temperature) is shown in figure 9. Data obtained from the tensile stress experiment of the nine samples have been listed in table 3 . The ultimate tensile stress (UTS) values for X70M steel is determined at $660.21 \mathrm{MPa}$, according to the API $5 \mathrm{~L}$ specification, [24] for pipeline application. Therefore, weld trial 4 parameters meet the specification requirements and therefore may be considered for the deep offshore (cold region) welding requirements.

In the analysis, area under the curve for the elastoplastic stress strain curve (figure 13) of the material that was obtained from the experiment - tensile strength of the nine (9) weld trials was used to assess the main objective of the work. All the curves superimposed to determine the largest area, which represents the strength of the material.

\subsection{Comparison of Results between the Experimental Model and FEA Model.}

The analysis results between the experimental model and FEA model (Table 7) revealed a difference of $0.77 \mathrm{MPa}$, this is negligible value and shows the validity of the experiment. However, the extension value difference is $6.7 \mathrm{~mm}$. This difference may be attributed to the effects of machine vibrations, human errors and some other factors.

\section{CONCLUSIONS}

Girth weld replica of the API X70M material have been produced using selected welding processes guided by Taguchi design method. It was observed from the results of tensile tests that weld trial 4, with arc voltage of $25 \mathrm{~V}$ and wire feed rate of 3.6 $\mathrm{m} / \mathrm{min}$ has the highest UTS of $660.21 \mathrm{MPa}$ and $\mathrm{S} / \mathrm{N}$ ratio of $56.40 \mathrm{~dB}$ respectively, indicating the best process parameters for the welding procedure. The analytical test from the MIDAS NFX FEA software shows similar strength level. Equally, ANOVA results shows that the Arc voltage has the most significant parameters in the welding process.

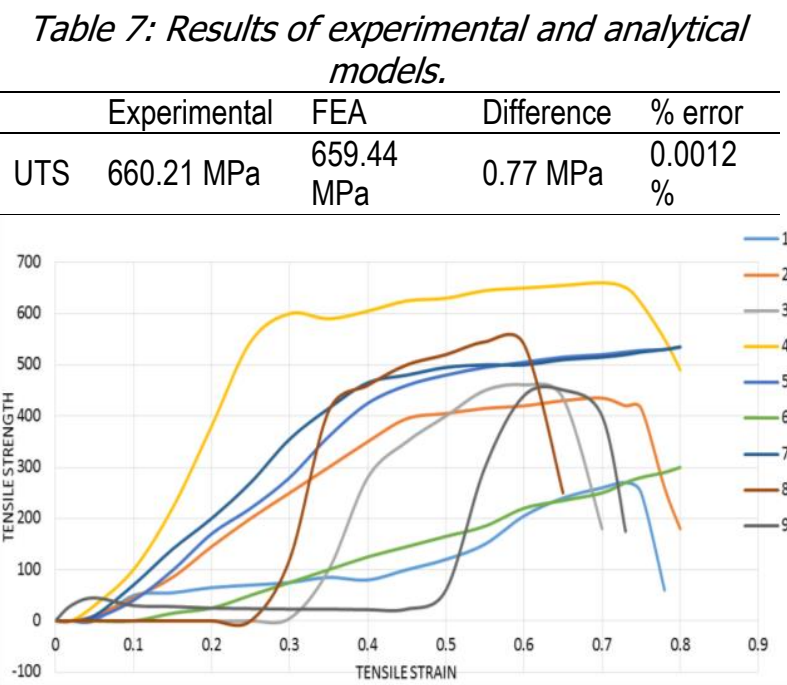

Figure 13: Superimposed graphs of tensile strengths of the 9 weld trials.

Additionally, the values of tensile strength achieved by each weld trial specimens obtained from the areas under the stress-strain curves were observed (figure 13) that the area under the curve of weld trial 4 is much larger than the other curves. Therefore, the mechanical properties of weld trial No. 4 could absorb more energy during impact conditions and resist the propagation of cracks.

The expected target of mechanical properties to produce welds having tensile strength within the range of $650-680 \mathrm{MPa}$ was achieved through this process. That is, welding process parameters of number 4 used, suits the major aim of the research work.

It is therefore recommended, as shown in figures 8 and 9, that tensile strength values, greater than 600 $\mathrm{MPa}$ can be obtained using an arc voltage between 24 and 29 volts with wire feed rate of between 3.6 and $4.2 \mathrm{~m} / \mathrm{min}$.

\section{REFERENCES}

[1] Shigeru O. and Hatsuhiko O., "Latest Advances and Future Prospects of Welding Technologies", Nippon Steel Technical Report No. 95, January 2007.

[2] Howard B. C. and Scott C. H., Modern Welding Technology, 6th ed., pg. 1-2, Pearson Prentice Hall, New Jersey, 2005.

[3] Malin, 'Monograph on Narrow-Gap Welding Technology," Bulletin 323, Welding Research Council, New York, May, 1987.

[4] Norrish J., Advanced welding processes: technologies and process control, Wood head Publishing and Maney Publishing, Cambridge, England, 2006. 
[5] https://www.google.com/imgres?imgurl. Accessed on the 12/07/2020.

[6] Vinay Kumar Pal, Dr. L. P. Singh, C.Pandey $A$ Comparative Study of Groove Design And Welding Process On Shrinkage Stress, Residual Stress And Tensile Properties Of P91 Steel. M. Tech, SHUATS, ALLAHABAD Department of Mechanical Engineering Sam Higgin bottom University of Agriculture, Technology and Sciences (U.P State Act No. 35of 2016, as passed by the Uttar Pradesh Legislature) Allahabad, India, 2016.

[7] Priti Sonasale, An Approach to Optimize MIG Welding Parameters by Using Design of Experiments. Department of Mechanical Engineering Central University of Karnataka Gulbarga, Karnataka, India, 2014

[8] Yong-Yi Wang, David Rudland, Rudi Denys, and David Horsley. A preliminary strain-based design criterion for pipeline girth welds. In 2002 4th International Pipeline Conference, pages 415427. American Society of Mechanical Engineers, January 2002. (Cited on page 9.)

[9] William Mohr, Robin Gordon, and Robert Smith. Strain-based design guidelines for pipeline girth welds. The Fourteenth International Offshore and Polar Engineering Conference, 1:10-17, January 2004. (Cited on page 9.)

[10] Martin W. Hukle, Agnes M. Horn, Douglas S. Hoyt, and James B. LeBleu. Girth weld qualification for high strain pipeline applications. In ASME 2005 24th International Conference on Offshore Mechanics and Arctic Engineering, pages 369-374.

[11] D. P. Fairchild, M. D. Crawford, W. Cheng, M. L. Macia, N. E. Nissley, S. J. Ford, D. B. Lillig, and J. Sleigh. Girth welds for strain-based design pipelines. In Proceedings of the 18th International Offshore and Polar Engineering Conference, Vancouver, Canada, pages 48-56.

[12] Fathi Hamad, Xiande Chen, and Laurie Collins. High toughness, submerged arc girth weld for northern pipeline applications. In 2006 International Pipeline Conference, pages 917925.

[13] Michael J. Gaudet, The Tensile Properties and Toughness of Microstructures Relevant to the HAZ of X80 Linepipe Steel Girth Welds. A Thesis Submitted In Partial Fulfillment of The Requirements For The Degree Of Doctor Of Philosophy In The Faculty Of Graduate And Postdoctoral Studies (Materials Engineering). The University of British Columbia (Vancouver) ANSI/ASME Standard B31.3, Standard for Chemical Plant and Petroleum Refinery Piping. New York City: ANSI/ASME, 2002.

[14] SUMI Hiroyuki, KATAOKA Tokihikoa and KITANI Yasushi. Application of Narrow Gap Welding
Process with "J-STAR TM Welding" to

Shipbuilding and Construction. JFE TECHNICAL REPORT. No. 20 (Mar. 2015)

[15] Chen Zhang, Geng Li, Ming Gao and XiaoYan Zeng. 2017. Microstructure and Mechanical Properties of Narrow Gap Laser-Arc Hybrid Welded $40 \mathrm{~mm}$ Thick Mild Steel Materials (Basel). 2017 Feb; 10(2): 106.

[16] M. A. Sholokhov, V. A. Erofeev \& S. I. Poloskov. Effect of deviations of the chemical composition of high-strength steel and electrode wire on the mechanical properties of narrow-gap welded joints, Welding International, 31:10, 791-795 2017

[17] Chenxiao Zhu, Xinhua Tang, Yuan He, Fenggui Lu, and Haichao Cui. 2016. Study on arc characteristics and their influences on weld bead geometry in narrow gap GMAW of $5083 \mathrm{Al}$-alloy. Int J Adv Manuf Technol. 90, 2513-2525 (2017).

[18] Jae-Seong Kim and Hui-Jun Yi, 2017. Characteristics of GMAW Narrow Gap Welding on the Armor Steel of Combat Vehicles. 1. IAE (Institute of Advanced Engineering.

[19] Kondapalli1 S. P., S. R. Chalamalasetti2 and N. R. Damera3. 2015. Application of Taguchi based Design of Experiments to Fusion Arc Weld Processes: A Review. International Journal of Business Research and Development. Vol. 4 No. 3, pp. 1-8, 2015.

[20] Rishi Pamnani, T. Jayakumar, M. Vasudevan, P. Vasantharaja. 2015. Optimization of A-GTAW welding parameters for naval steel (DMR 249 A) by design of experiments approach. Proc IMechE Part L: J Materials: Design and Applications. 0(0) 1-12! IMechE 2015.

[21] A.O. Osayi, E.A.P. Egbe, S.A. Lawal. 2015. "Optimization of Process Parameters of Manual Arc Welding of Mild Steel Using Taguchi Method". American Journal of Mechanical Engineering, Vol. 3, No. 3, 93-97, 2015.

[22] Shyam Kumar Karna and Dr. Rajeshwar Sahai, "An Overview on Taguchi Method". Ph.D. Scholar, A.P. (Mech), ACME, Palwal, Associate Professor (Mech), MRIU, Faridabad. International Journal of Engineering and Mathematical Sciences IJEMS. Volume 1), pp.1118, Jan.- June 2012.

[23] Norasiah Muhammad, Yupiter HP Manurung, Mohammad Hafidzi, Sunhaji Kiyai Abas, Ghalib Tham and Esa Haruman, Optimization and modeling of spot welding parameters with simultaneous multiple response consideration using multi-objective Taguchi method and RSM+ Journal of Mechanical Science and Technology 26 (8) (2012).

[24] API 5L, Specification for Line Pipe, vol. 42 (American Petroleum Institute), p. 153, 2000. 